American Journal of Environmental Sciences 4 (6): 558-568, 2008

ISSN $1553-345 \mathrm{X}$

(C) 2008 Science Publications

\title{
Impact of Emissions from Power Stations on the Ambient Air Quality of Selected Urban Areas in Kuwait
}

\author{
${ }^{1}$ Bader N. Al-Azmi, ${ }^{1}$ V. Nassehi and ${ }^{2}$ A.R. Khan \\ ${ }^{1}$ Department of Chemical Engineering, Loughborough University, Leicestershire, LE11 3TU, UK \\ ${ }^{2}$ Department of Coastal and Air Pollution, Kuwait Institute for Scientific Research, Kuwait
}

\begin{abstract}
In Kuwait, two main power stations, one comprising of seven-300MW steam generators at Doha and other with eight-300MW steam generators at Subyia cover the major power requirement of Kuwait city. These stations used different types of fuel oil as the prime source of energy that has different sulpher contents (S\%). Comprehensive emission inventories for year the 2001 were used to execute Source Complex model for Short-term Dispersion (ISCST4.5) to predict ambient ground level concentrations of sulphur dioxide $\left(\mathrm{SO}_{2}\right)$ and nitrogen oxide (NOx) at selected receptors. A yearlong meteorological data were used in conjunction with the dispersion model to compute $\mathrm{SO}_{2}$ and $\mathrm{NOx}$ levels in and around the power stations. For validation of the model, computed results were compared with the measured daily average values at a fixed Kuwait EPA air quality monitoring station located at the roof of polyclinic in Rabia residential area. Contributions of each power station to the highest predicted values were assessed. Significance of the fifty highest hourly, daily and annual ground level concentration values under existing meteorological conditions was analyzed. The results for year 2001 revealed that daily and annual mean predicted $\mathrm{SO}_{2}$ concentrations had exceedance about $5.7 \%$ and $0.16 \%$ respectively of the total area under investigation. Based on these results, mitigation strategies would be proposed to abate high pollution levels caused by these power stations.
\end{abstract}

Key words: Air pollution, ISCST4.5, sulphur dioxide, nitrogen oxide

\section{INTRODUCTION}

Rapid industrialization worldwide has triggered off a wave of economic development bringing prosperity and advancement for many nations. However, such activity has not been without degradation of the environment, through the depletion and contamination of existing natural resources and discharge of pollutants into air, water and dumping of solid waste on land. All of these have exerted an enormous load on the environment as a whole damaging the quality of resources available to all existent life forms.

Air Pollution is amongst the most serious global environmental concerns. Apart from incidents and mishaps such as London Fog, Bhopal Gas Tragedy, there are cases that have long-term hazards and need to be addressed urgently. Amongst these are the Ozone Hole problem, Global Warming issue and Acid Rain problem. These concerns however, have led to the formation of specific governing bodies regulating emissions, laws and regulations for controlling these problems.
They have also led to the setting up of treaties such as the Kyoto Protocol, Montreal protocol, Nitrogen oxide protocol and the declaration of representative dates like as June 5-World Environment Day, April 22-Earth Day and September 16-International Day for the Preservation of the Ozone layer.

In the study of air pollution, it is essential to have a complete insight into the nature, behavior and characteristics of a pollutant along with the prevalent meteorological characteristics of the environment into which it is released. This provides the basic data regarding its impact on the environment as well as developing effective measures to check its impairing properties and control the damage that can be caused to nature. Gokhale and Khare ${ }^{[1]}$ have established an empirical relationship between the pollutants concentration in the air and meteorological parameters that has facilitated the construction of design methodologies for the protection of environment. However, in the last decade statistical models have been used more than the traditional deterministic $\operatorname{models}^{[2]}$.

Corresponding Author: Bader N. AL-Azmi, Department of Chemical Engineering, Loughborough University, Leicestershire, LE11 3TU, UK Tel: 965-6698833 
Computer techniques used in conjunction with both deterministic and statistic approaches provide powerful tools to study the impact of pollutants on the environment. They also enable prediction of likely outcomes and help to develop environmental safe guards. These models validated with actual field and laboratory data help to verify the authenticity of novel approaches and their compatibility with the Environmental Protection Authority (EPA) criteria. Therefore, air quality models are indispensable tools for evaluating the impact of air pollutants on urban environments and human health ${ }^{[1]}$.

The economy of Kuwait is predominantly supported by petroleum industry, one of the key natural resources of the country. Considering the size of this industry in Kuwait significant impact to the environment can be expected as an obvious outcome. Oil production rate of Kuwait currently stands at two $\mathrm{m}$ barrels per day and the supporting infrastructure required to manage this level of oil production complicates the situation. Kuwait EPA has set up a number of monitoring stations (eight) to keep a track of pollutants emission through a monitoring network. In parallel with oil industry, another source that has become a key concern is the growing power consumption.

Kuwait is an arid desert, with unsympathetically hot summers, which dominate a major portion of each year. Summer temperatures can reach up to $50^{\circ} \mathrm{C}$ and adequate cooling and air conditioning in any way that modern living condition can be satisfy. To satisfy this need a network of power stations, which simultaneously also fulfill the nation's freshwater requirements need to operate to full capacity. Air Pollution can be described as the alteration of natural characteristics of the atmosphere chemically, either biologically or through introduction of particulates into it. Complex, yet naturally prevalent, structure and composition of the atmosphere helps sustain various life forms on Earth and any alteration of its composition can have grave consequences for upholding ecological balance. From a chemical point of view, this balance is disturbed by the emission of oxides of nitrogen $\left(\mathrm{NO}_{\mathrm{x}}\right)$ and sulfur $\left(\mathrm{SO}_{2}\right)$ and ozone $\left(\mathrm{O}_{3}\right)$. Particulates grouped generally under TSP (total suspended particles) are also a major concern worldwide, with a significant impact on human health. Nitrogen oxides act as precursors to generation of ozone, while individually being responsible for most types of asthmatic conditions. They can also contribute to the formation of nitric acid by reacting with oxidizing agents and water and hence along with sulfur dioxide play an active role in the acid rain problem.
Hydrogen sulfide on the other hand is a menace by itself. Therefore, monitoring stations of Kuwait environmental protection authority (K-EPA) are required to measure a spectrum of pollutants such as $\mathrm{SO}_{2}, \mathrm{NO}_{2}, \mathrm{CO}, \mathrm{CO}_{2}, \mathrm{H}_{2} \mathrm{~S}, \mathrm{O}_{3}$ and TSP in order to study their possible impacts on the environment as well as their corrosive effects on materials ${ }^{[3]}$. The aim of the present study has been to utilize a well established computer modeling methods to evaluate the impact of various pollutants on the air quality in Kuwait. Inputs required in the model are geographical data of the area of concern, pollutant sources, emission rates and corresponding real-time meteorological conditions. Model results are compared with the collected observed data for verify the applicability of the approach.

\section{DISCRIBTION OF THE STUDY AREA (GRAPHICAL DATA)}

The State of Kuwait is boarded in the east by the sea, by the Kingdom of Saudi Arabia in the south and southwest and in the north and the northwest by the Republic of Iraq. The weather in winter is comfortably cool and during nights sometimes can be cold with temperature dropping blow $5^{\circ} \mathrm{C}$. In summer, the outstanding features are heat and the dryness of the air. The mean temperature in July and August ranges from $40-50^{\circ} \mathrm{C}$ with an average mean daily maximum of nearly $45^{\circ} \mathrm{C}$ occasionally reaching $50^{\circ} \mathrm{C}$.

Figure 1 shows the distance between the farthest northern and southern points of the state boundaries that is about $200 \mathrm{~km}$ and from farthest east to west, which is about $175 \mathrm{Km}$. The total length of the border lines about $690 \mathrm{~km}$, about $200 \mathrm{~km}$ of these borders to the east is maritime borders. The land frontiers are $490 \mathrm{~km}$ of which $250 \mathrm{~km}$ form the frontiers with the Kingdom of Saudi Arabia in the South and West and $240 \mathrm{~km}$ is the length of frontier with the Republic of Iraq in the North and West. The total area of the State of Kuwait is 17,818 square kilometers. The highest concentration of residential areas is in the southeast edge of the Kuwait Bay occupying only $7 \%$ of the total area of the country. The land surface in Kuwait slopes down gently From West to East.

Rabia area was the most appropriate location chosen for the purpose of this study. Kuwait municipality's 2003 records describes Rabia as a relatively run down residential suburb of central Kuwait, covering a total area of $2.456 \mathrm{~km}^{2}$. Rabia has a total population of 30000-35000, housed in five residential blocks, comprised of a total of 320 houses, sharing services of 14 co-operative stores, 20 main 
Am. J. Environ. Sci., 4 (6): 558-568, 2008

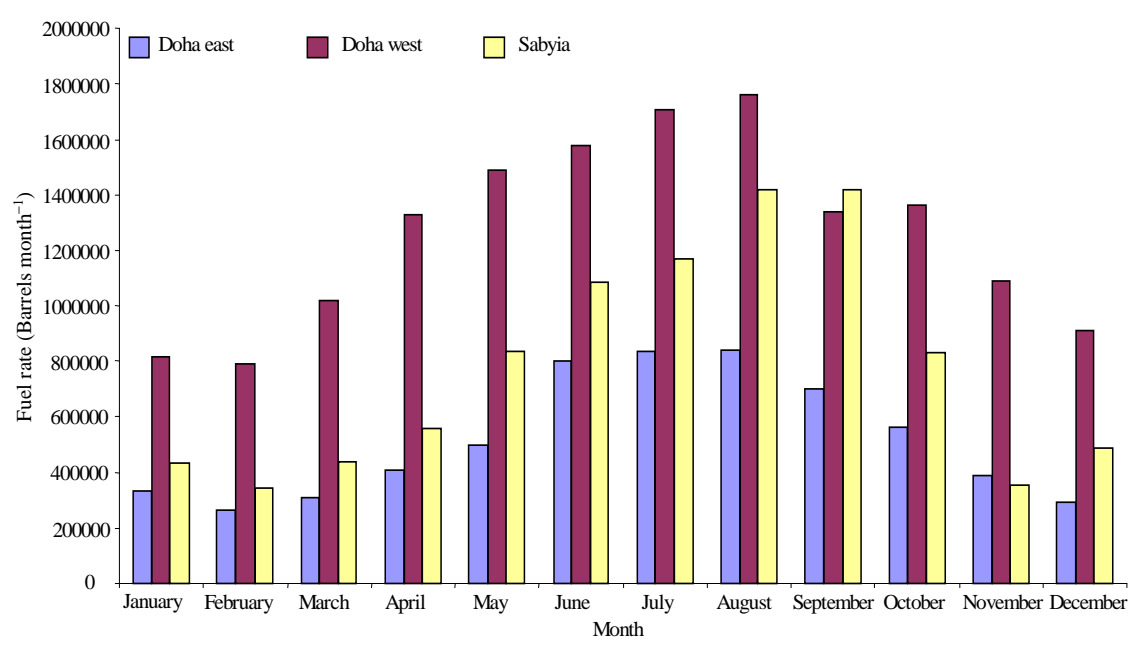

Fig. 1: Consumption of oil (barrels per month) during year 2001

electrical stations, two petrol stations (one in the east and the other in the west) a community hall and a restaurant. Civic amenities include seven schools, a police station and a polyclinic. Although a predominantly residential neighborhood (with the exception of Shuwaikh industrial area to the north), alarming air pollution load in Rabia presents a problem. The district lies between three major highways, 5th ring road at the northern end, 6th at the south and Gazalli expressway, stretching along its eastern border. Kuwait International Airport is located further towards southeast. The airport traffic is apparently consistent and the road traffic has two distinct trends, a congested flow between 7:00 and 9:00 am repeated again between 5:00 and 8:00 pm. However the main source of pollutants are the power stations of Doha complex in the northwest and Subyia to the northeast. An important reason for selecting Rabia as a study area is the fact that an air quality monitoring station is located at the roof of Rabia polyclinic. Data records from this station based on 5 min measurements together with meteorological conditions and subsequent $1 \mathrm{~h}$ averages are generated using an excel based macro. This provided measured ground level concentrations to validate the model output in this study. In addition to the power plants, other main cause of air pollution in Rabia is traffic, partly from the highways surrounding the area and partly from the transport offices located in nearby Ardiya, which have large trailer convoys, offering goods and services on a cross-country basis. Another transport activity that contributes to the air pollution is the Kuwait International Airport, located at the southeast of Rabia with its significant air traffic volumes. Relatively minor source of pollution are AlRai industrial area, located towards the north with numerous garages that offer automobile repair services and workshops for manufacturing paints, chemicals and welding works and the Ardiya sewage treatment plant and a small restaurant that is uses charcoal fires in its kitchen. However, the major source of air pollution in Rabia is the power plants.

\section{METROLOGICAL CONDITIONS}

In reality, Kuwait has only two distinct seasons, summer and winter, each lasting for almost six months. However, for the purpose of this study, these two representative seasons are broken down further into four periods, namely summer, autumn, winter and spring, which are divided into three months each. Summers are dry and harsh, with day temperatures of about $50^{\circ} \mathrm{C}$. Summer months are almost intolerable without significant air conditioning, which leads to high rates of power consumption. In summer, winds are considerably turbulent and are predominantly in northwest direction. This favors effective pollutant dispersion accompanied with a high inversion layer. In autumn, conditions become much more bearable. Winters are cold and damp, with rains causing further drop in temperature, which falls on occasions to $0^{\circ} \mathrm{C}$ during nights. Wind conditions in winters are calm and hence, accompanier with a low inversion layer which gives rise to poor pollutant dispersion. Spring represents the transition from winter to summer and is the most pleasant season in Kuwait. There is no observable change in the wind direction, either diurnally or seasonally. As expected the meteorological conditions play a pivotal role in pollutant dispersion affect the ground level concentrations in the residential areas. The meteorological parameters that are expected to affect $\mathrm{SO}_{2}$ and $\mathrm{NOx}$ concentrations are wind speed, 
wind direction, mixing height, ambient temperature and inversion layer.

Figure 2 shows that the prevailing wind direction was from northwest (NW) for about $60 \%$ of the time for year 2001 and about $20.1 \%$ of time winds could be describe as calm. Moreover, Fig. 3 shows the frequency distribution of the winds as $31.1 \%$ of recorded wind speed between 3.3-5.4 m sec ${ }^{-1}$ and about $16.3 \%$ between 1.8-3.3 m sec${ }^{-1}$. Low to medium strength winds blowing from the direction of power stations towards highly populated residential areas of Rabia no doubt increase pollution levels that can eventually affect the health of the people living there. Wind speed is a very important parameter affecting the dispersion process of pollutants. Wind speed and concentrations of pollutants downwind of a source are inversely related. Therefore, when the wind speed reaches its highest level it helps in reducing the concentration of any air

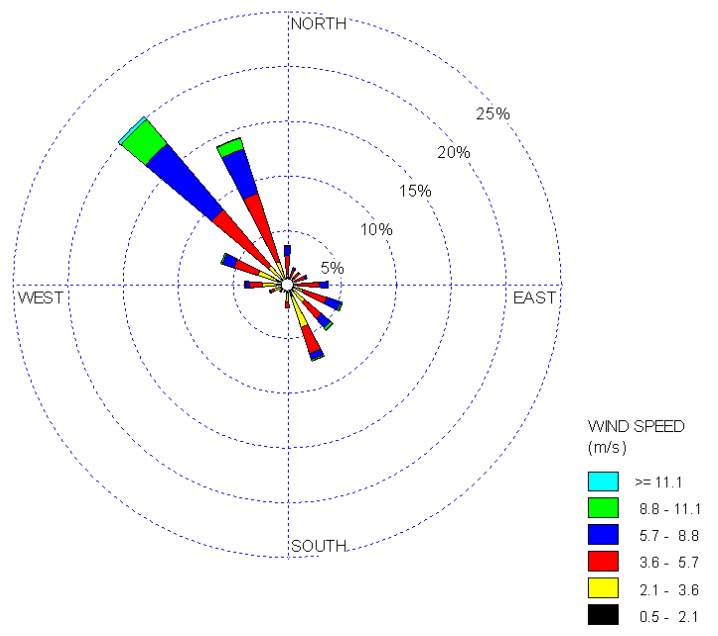

Fig. 2: Wind rose plot for year 2001

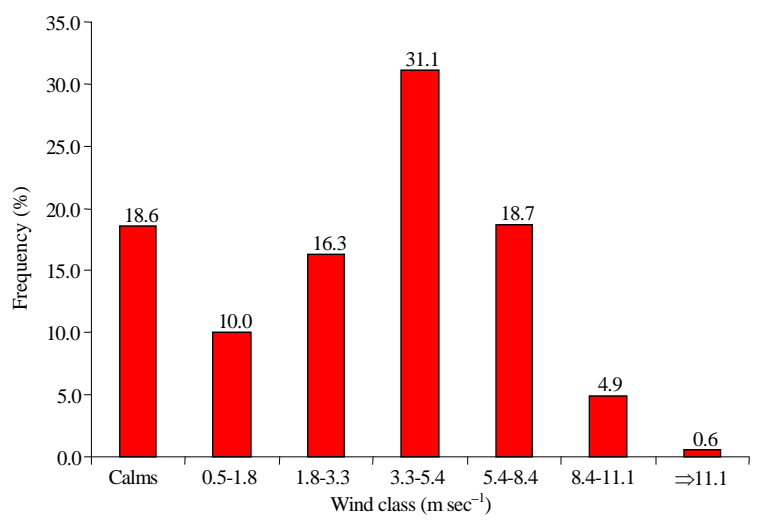

Fig. 3: Frequency distribution of the wind speed class during the year 2001 pollutant and thus serves to reduce its hazardous effects. On the other hand, slow wind can be considered as disadvantageous since it allows for the formation of high concentrations of pollutants moving slowly over residential areas and thus increasing the pollutants and their hazardous effects. Winters in Kuwait are characterized by low temperature, low inversion layers, lesser wind movements, which do not promote the dispersion of pollutants as compared to summers, which have high temperature, high inversion layers, high wind movements and effective distribution and dilution of pollutants. The prevailing winds in Kuwait are from the northwesterly quadrant throughout the year, about $60 \%$ of the time.

\section{EMISSION INVENTORY}

Sulphur and sulphur dioxide are prevalent in most types of fossil fuels such as oil, coal and in ores containing metals like copper, zinc, aluminum, iron and lead. Therefore when Sulphur containing fuels are used for power generation or during metal extraction processes sulphur dioxide is released into the atmosphere. $\mathrm{As}_{\mathrm{SO}_{2}}$ dissolves in water it forms acid, which reacts with other gases and particles to form sulphates. All of these substances are harmful to various life forms, particularly humans and the environment. Sulphur dioxides $\left(\mathrm{SO}_{2}\right)$ produced by the oxidation of sulphur contained in fossil fuels may be up to $90 \%$ of total emission with rest released as $\mathrm{SO}_{3}$ and $\mathrm{H}_{2} \mathrm{SO}_{4}$. The major sources of $\mathrm{SO}_{2}$ emission in Kuwait are the power stations and water desalination, which together are responsible for $67 \%$ of total load (US Environmental Protection Agency). The power plants are also the important sources of the emission of nitrogen oxide (NOx) equal a total load of $22 \%$. These power stations use four different types of fossil fuels all containing sulphur. The emissions from the power plants include $\mathrm{SO}_{2}, \mathrm{NOx}, \mathrm{VOC}$, which are transformed to Acid Rain and TSP in the form of ash, which in dry weather become deposited on surfaces. The fuel provided by Kuwait Oil Company (KOC) to these stations is mainly low sulphur fuel oil, gas oil, crude oil and heavy oil. The total sulphur contents by weight in these fuels are $0.5,1,2.5$ and $4 \%$, respectively. However, the Ministry of Electricity and Water $(\mathrm{MEW})^{[4]}$, rarely uses the low sulphur fuel oil because of economic reason. The following formula relates to the fuel consumption volumes of the $\mathrm{SO}_{2}$ emissions:

$$
\mathrm{Q}=\mathrm{FS}\left(\mathrm{SO}_{2}\right) \mathrm{MW} /(\mathrm{S}) \mathrm{MW}
$$

Where:

$$
\begin{array}{ll}
\mathrm{Q} & =\mathrm{SO}_{2} \text { emission rate }\left(\mathrm{g} \mathrm{sec}^{-1}\right) \\
\mathrm{F} & =\text { Fuel consumption }\left(\mathrm{g} \mathrm{sec}^{-1}\right) \\
\mathrm{S} & =\text { Sulfur content weight fraction in fuel }
\end{array}
$$


$\left(\mathrm{SO}_{2}\right) \mathrm{MW}=$ Molecular weight of $\mathrm{SO}_{2}=64 \mathrm{~g} \mathrm{moL}^{-1}$ (S) $\mathrm{MW}=$ Molecular weight of $\mathrm{S}=32 \mathrm{~g} \mathrm{moL}^{-1}$

Nitrogen oxides, generally represented as NOx, are the generalized category of compounds, composed of Nitrogen and Oxygen in varying concentrations, generally colorless, odorless and found abundantly in most urban areas worldwide. They are formed because of combustion processes (mainly when fuel burns at a high temperature). These oxides react to produce nitrates and nitric acid that cause smog and acid rain, as well as acting as a catalyst in the formation of harmful ground-level ozone. At high temperatures, oxygen and nitrogen react forming $\mathrm{NO}$ and $\mathrm{NO}_{2}$ and $\mathrm{NOx}$ formation increases exponentially as temperature rises. Bouhamra and Abdul-Wahab ${ }^{[5]}$, reported that traffic in the residential areas of Kuwait is responsible for the emissions of $26 \%$ of total NOx and $96 \%$ of total CO present in ambient air. Power station at Subyia has 8 , Doha west has 8 and Doha east has stacks. Therefore, total emissions are divided equally between 23 stacks to obtain the rate per stack. Table 1 shows physical stacks properties for each power plant. In addition, the

Table 1: Sources parameters input to the ISCST 4.5 model

\begin{tabular}{|c|c|c|c|}
\hline Station & Doha East & Doha West & Subyia \\
\hline Number of stacks & 7 & 8 & 8 \\
\hline $\begin{array}{l}\text { Location coordinate } \\
\text { in UTM E-W (X) (m) }\end{array}$ & 771416.8 & 770561.3 & 808643.5 \\
\hline $\begin{array}{l}\text { Location coordinate } \\
\text { in UTM N-S (Y) (m) }\end{array}$ & 3252100.7 & 3251990.5 & 3276032.3 \\
\hline $\begin{array}{l}\text { Base elevation from } \\
\text { sea level }(\mathrm{m})\end{array}$ & 4 & 4.5 & 4.1 \\
\hline Stack height (m) & 196 & 190 & 192 \\
\hline Exit temperature $(\mathrm{K})$ & 408 & 403 & 426 \\
\hline Exit velocity $\left(\mathrm{m} \mathrm{s}^{-1}\right)$ & 29.4 & 29.4 & 28.8 \\
\hline Exit diameter $(\mathrm{m})$ & 3.5 & 4.3 & 4.3 \\
\hline
\end{tabular}

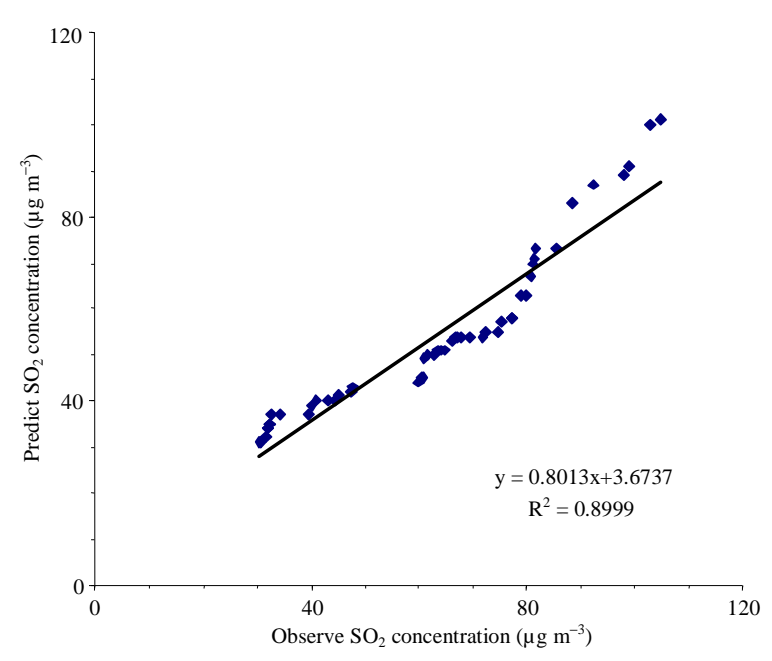

Fig. 4: The highest fifty values of the predicted daily concentration of $\mathrm{SO}_{2}\left(\mu \mathrm{g} \mathrm{m}^{-3}\right)$ V.S. The highest fifty values of the observed daily concentration of $\mathrm{SO}_{2}\left(\mu \mathrm{g} \mathrm{m}^{-3}\right)$ in year 2001 emission rates represent the total amount of the monthly variations for the year 2001, as shown in Fig. 4, which reflect oil consumption at the power stations indicating the greatest consumption in summer season.

\section{MODEL DETAILS}

In this study, the Industrial Source Complex for Short-term Dispersion (ISCST4.5) model approved by U.S. EPA is used. This model provides options to model emissions from a wide range of sources that might as pollution sources. Model ISCST4.5 is considered a powerful tool for most air pollution studies, including emission rate of sulphur dioxide $\left(\mathrm{SO}_{2}\right)$ and nitrogen oxide (NOx) and the determination of temporal and spatial variations of ground level concentrations of $\mathrm{SO}_{2}$ and $\mathrm{NOx}$.

Therefore, it is used to model the impact of emissions from Doha and Subyia in power plants. Results the ISCST4.5 model in the present study are compared with observed data collected at the station located above the polyclinic in Rabia. One of the aims of this study has been the investigation of the performance of the ISCST4.5 model under the prevailing meteorological conditions in Kuwait. Successful application of any mathematical model depends on the quality of the emission inventory data for all sources and meteorological data ${ }^{[6]}$.

The ISCST4.5 model is based on a straight line, steady state bi-Gaussian plume equation. This model uses the Gaussian plume simplification of the three dimensional convective-diffusion equation to calculate hourly, daily, monthly and annual averages of the ground level concentrations of a pollutant released from elevated sources under varying realistic meteorological conditions.

The model includes reflection from the ground, elevated dispersion ceiling and the dispersion parameter formulas derived from Pasquill and McElroy-Pooler data and the plume rise formula of Briggs. It also taken into account stack-tip downwash, wind profile, buoyancy-induced dispersion, urban and rural dispersion and terrain adjustment algorithm. A detailed description of ISCST4.5 model can be found in US $\mathrm{EPA}^{[7]}$.

Previous modeling studies such as the study presented by Al-Rashidi et $a .^{[8]}$, for predicting the dispersion of $\mathrm{SO}_{2}$ from the power stations and to investigate the efficiency of existing $\mathrm{SO}_{2}$ level monitoring stations in the state of Kuwait are also revaluated in this research. In addition, many previous modeling studies such as the studies presented by AlSudairawi and Mackay ${ }^{[9]}$ and Abdul-Wahab et al. ${ }^{[10]}$, which use different ISC models to predict the 
dispersion of $\mathrm{SO}_{2}$ from the Shuaiba Industrial Area (SIA) are also critically evaluated. In most of previews work, the topographical effects are not taken into account that may result in poor quality of the modeling simulations. Details of the ISCST, environmental model is given in many studies elsewhere ${ }^{[7,11]}$.

The present model takes into consideration the impact of settling criteria, sources (line and point), pollutant decay, emission rate alterations and landscape details on plume dispersion. The model has three main input data requirements, namely source information (emission rate, stack height, inner exit diameter, gas discharge speed, temperature, height above sea level, etc.) which obtained from Ministry of Electricity and Water (MEW). The second input meteorological information (wind speed, wind direction, air temperature, mixing height, stability class, during the measurement instance, etc.) and the third input is receptor information (in order to forecast pollutant concentration at various points on the mesh).

Two types of receptor coordinates are used in the present model. These are Discrete Cartesian Receptors and Uniform Cartesian Receptors. The selection of receptors is based on their actual site in term of UTM (Universal Transverse Mercator) location coordinate of Kuwait. Meteorological data were obtained from Kuwait International Airport (AIP) for this model, which give data about relative humidity, wind speed, wind direction, temperature and inversion layer, based on hourly measurements. This data include stability class which is an index based on hourly measurements wind speed and cloud cover, as Pasquills categories ${ }^{[12]}$. This data along with the mixing height, are used in the model. The ISCST model is used together with PCRAMMET, which is a metrological preprocessor for preparing National Weather Service (NWS) data ${ }^{[13]}$. The PCRAMMET is used to estimate the hourly stability class and the hourly mixing height. Meteorological data obtained from Kuwait Airport for the year 2001 is used to run PCRAMMET to generate the meteorological input file for running of the ISCST4.5 model.

\section{RESULTS AND DISCUSSION}

The ISCST 4.5 model software was run using to the emissions from the stacks of the power plants using three selected mesh areas. The first area covering the total selection mesh area of $2400 \mathrm{~km}^{2}$ with 2500 receptors comprises of single cells of $1 \mathrm{~km}^{2}$. The second mesh covers only the Doha power station with area of $100 \mathrm{~km}^{2}$ and single cells of $0.25 \mathrm{~km}^{2}$. The third mesh covers only the Subyia power station with total area of $100 \mathrm{~km}^{2}$ and single cell of $0.25 \mathrm{~km}^{2}$. The used mesh defined coordinates in term of $\mathrm{X}$ and $\mathrm{Y}$-axis, contains selected source and receptor location. As discussed above, the sources of various pollutants are many, but for the purpose of this study, we have considered only the impact due to the power stations. The Doha power station has two stacks East and West. The East stack consists of three chimneys, while the West stack consists of four, collectively referred to as Doha Complex. The Subyia has two stacks each consisting of four chimneys. The number of points considered for the first mesh include 50 on the $\mathrm{X}$-axis, which has a total length of $49 \mathrm{~km}$, with a spacing of $1 \mathrm{~km}$ between two points and 50 on the Y-axis, which has a total length $49 \mathrm{~km}$ and a spacing of $1 \mathrm{~km}$ between points. Collectively this makes up 2500 receptors, in a Uniform Cartesian Grid. The single receptor of interest, Rabia is referred to as the Discrete Cartesian. The second and third mesh areas have 21 points on $\mathrm{x}$-axis and 21 points on $y$-axis. These axes have a total length around $10 \mathrm{~km}$ in $\mathrm{x}$ and $\mathrm{y}$ each with spacing of $0.5 \mathrm{~km}$ between two points in both meshes. Therefore, 441 receptors for each mesh are considered. The total number of receptors in the three mesh areas is 3383. In making the described, mesh arrangements the geographical shape as dimension of Kuwait have been taken into account. The closest residential areas to the Doha Complex are Doha residential area, located at a distance of $6.5 \mathrm{~km}$ and Sulaibikhat located at a distance of $8 \mathrm{~km}$, both in SE direction. The closest residential area to Subyia is the Kuwait city located $25.4 \mathrm{~km}$ in the $\mathrm{SW}$ direction, on the other side of the Kuwait Bay. The distances between Rabia and Doha East and Doha West are 16.5 and $17 \mathrm{~km}$, respectively. The distance between Rabia and Subyia is $39.5 \mathrm{~km}$.

Figure 5 shows the $\mathrm{SO}_{2}$ emission rate from the power stations for the year 2001. The highest overall consumption of fuel was recorded in the summer season, due to the heavy load during this period and the lowest during winter. Doha west recorded $1.75 \mathrm{~m}$ barrels consumed in August, while Subyia used $1.42 \mathrm{~m}$ barrels and Doha east, $0.82 \mathrm{~m}$ barrels. The lowest consumption was reported in February, Doha west using $0.79 \mathrm{~m}$ barrels, Subyia $0.36 \mathrm{~m}$ barrels and Doha east $0.26 \mathrm{~m}$ barrels. With respect to emissions, there is a similar trend, with, Doha west ranking highest in emissions, followed by Subyia and finally Doha east.

The highest recorded $\mathrm{SO}_{2}$ emission from Doha west was $7000 \mathrm{~g} \mathrm{sec}^{-1}$ in August, followed by the months of July and June and the lowest in February. Subyia registered the highest emission of $4650 \mathrm{~g} \mathrm{sec}^{-1}$ in July, followed by August and June and the lowest in February. Doha East recorded a maximum of $2700 \mathrm{~g} \mathrm{sec}^{-1}$ in August, followed by July and then September and October. The lowest was recorded in March. 
Figure 6 represents the emission rates of NOx that are high during the summer season. NOx emissions for Subyia were equally high in summer, which seems to be masked in the case of $\mathrm{SO}_{2}$ emissions. The highest emission rate reported was $620 \mathrm{~g} \mathrm{sec}^{-1}$ at Subyia in the month of July, followed by $610 \mathrm{~g} \mathrm{sec}^{-1}$ in the month of August. The highest emission rate at Doha west was 595 $\mathrm{g} \mathrm{sec}^{-1}$ in the month of August while the emissions due to Doha east were far lesser, with the maximum value reported at $305 \mathrm{~g} \mathrm{~s}^{-1}$ in the month of August. The lowest NOx recorded emission rate at Subyia was $110 \mathrm{~g} \mathrm{sec}^{-1}$ in the month of November, while the lowest value recorded at Doha west was $285 \mathrm{~g} \mathrm{sec}^{-1}$ in the month of January. The lowest emission ate at Doha east was $80 \mathrm{~g} \mathrm{sec}^{-1}$ in the month of April. This is in concordance with oil consumption at all the three sources, which has the greatest at Doha west, exhibiting the top four values in summer, 1.78, 1.75 and 1.59 mbarrels respectively, followed by 1.41 , at Subyia again in summer. The highest consumption values, $0.82,0.81 \mathrm{~m}$ barrels at Doha east are also displayed in summer. The lowest consumption values at all three sources are documented in winters, specifically in February, 0.79 at Doha west, 0.27 at Subyia and 0.23 at Doha east.

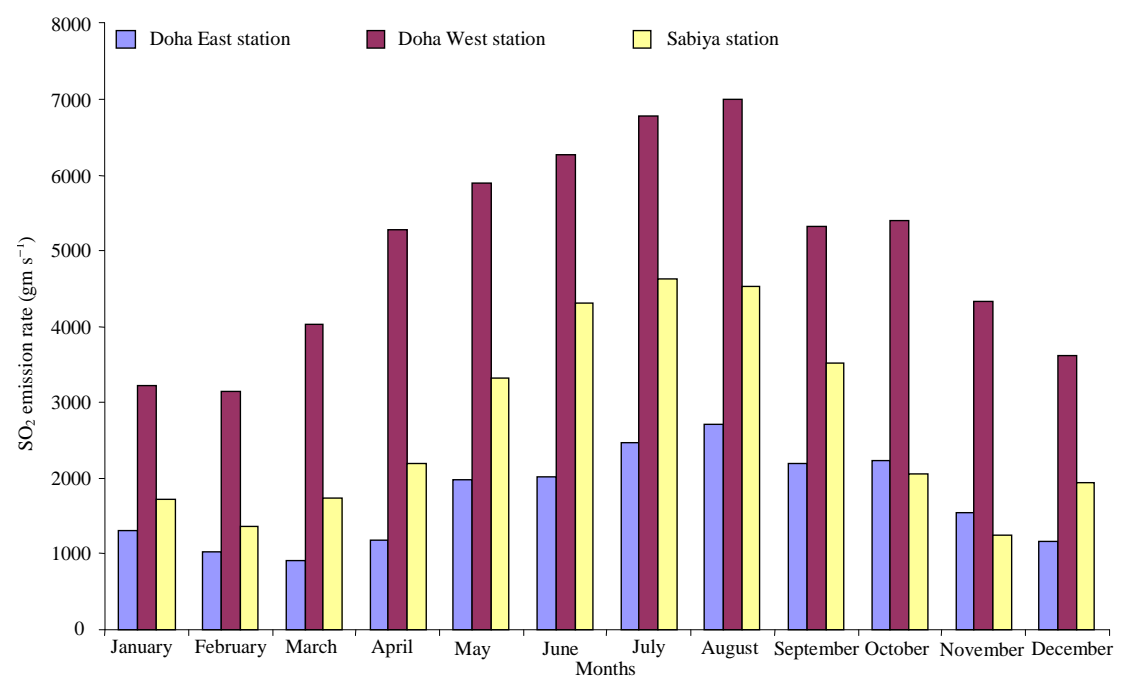

Fig. 5: The emission rate of $\mathrm{SO}_{2}$ in $\left(\mathrm{g} \mathrm{sec}^{-1}\right)$ from two power stations for year 2001

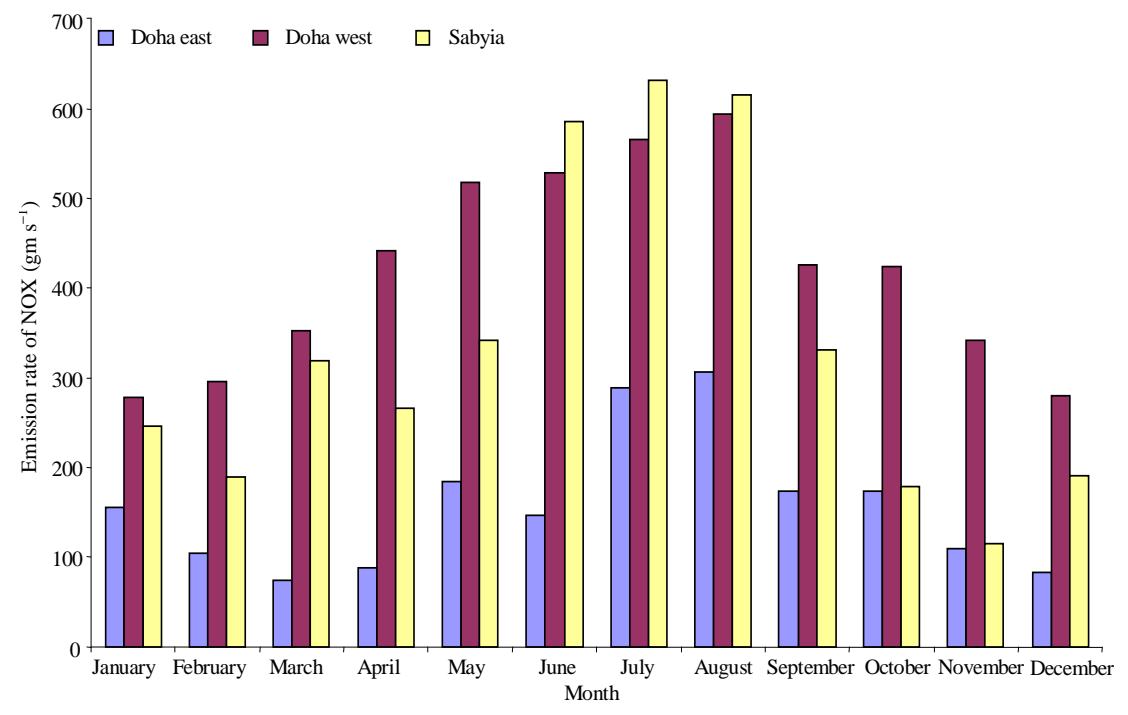

Fig. 6: The emission rate of NOx in $\left(\mathrm{g} \mathrm{sec}^{-1}\right)$ from two power stations for year 2001 
For the model validation purposes, the predicted results are compared with the actual real time measured values for sulfur dioxide, from the monitoring station located above the polyclinic in Rabia. Figure 4 shows the slope of the predicted daily $\mathrm{SO}_{2}$ concentration against the observed values which is equal to the 0.8 . This proves the accuracy of the model. Any discrepancy is due to the contribution from other $\mathrm{SO}_{2}$ sources than the power stations. It has not been possible to compare predicted NOx concentrations due to the high impact of diverse sources (road traffic, domestic fuel use, industrial emissions etc.) contribute on a large scale to the overall NOx load of the ambient air. It has been reported that power stations contributed about (22\%) and vehicular traffic about (55\%) (US EPA) to the total NOx concentration in urban areas. Figure 7 and 8 show the concentration roses of the sulfur dioxide $\left(\mathrm{SO}_{2}\right)$ for the highest fifty values. As shown in Fig. 7 and 8 the specified limits set to KuwaitEPA for hourly and daily emissions over the selection mesh area are violated. In the case of daily concentration the concentration roses indicate the highest values towards southeast (SE) direction, which is the same as the predominant wind direction for the entire year. The predicted pollutant concentrations are the highest in southeast of this sector, reflecting the dominant influence of the wind direction. The highest daily value observed was $932 \mu \mathrm{g} \mathrm{m}^{-3}$, on the 9th of July 2001, $1.4 \mathrm{~km}$ from the Doha station and $157^{\circ}$ bearing north. The second highest observed value again was $794 \mu \mathrm{g} \mathrm{m}^{-3}$, on the 21st of August 2001, $1.36 \mathrm{~km}$ from Doha station $157^{\circ}$ bearing north.

It is obvious from the presented isopleths diagrams that high concentrations are predicted as two elliptical loops in downwind (SE) and upwind (NW) directions. This clearly agrees with the prevalence of a northwesterly wind direction. The daily pollutant concentrations have an average value for $24 \mathrm{~h}$ that has suppressed hourly variation in meteorological conditions and showed the high values in southeastern sector. The predicted values also confirm the expected fading of high concentrations as the plume moves from the source. On the hourly basis, the highest value observed was $4421 \mu \mathrm{g} \mathrm{m}^{-3}$, on the 3rd of August 2001, at $1.6 \mathrm{~km}$ from Doha station and $86^{\circ}$ bearing north. The second highest value was $3944 \mu \mathrm{g} \mathrm{m}^{-3}$, on the $3 \mathrm{rd}$ of August 2001, at $1.55 \mathrm{~km}$ from Doha station source and $81^{\circ}$ bearing north. These values occurred at 4:00am in early morning both cases reflecting the influence of meteorological conditions (low temperature, calm wind and low inversion layer). The hourly concentrations

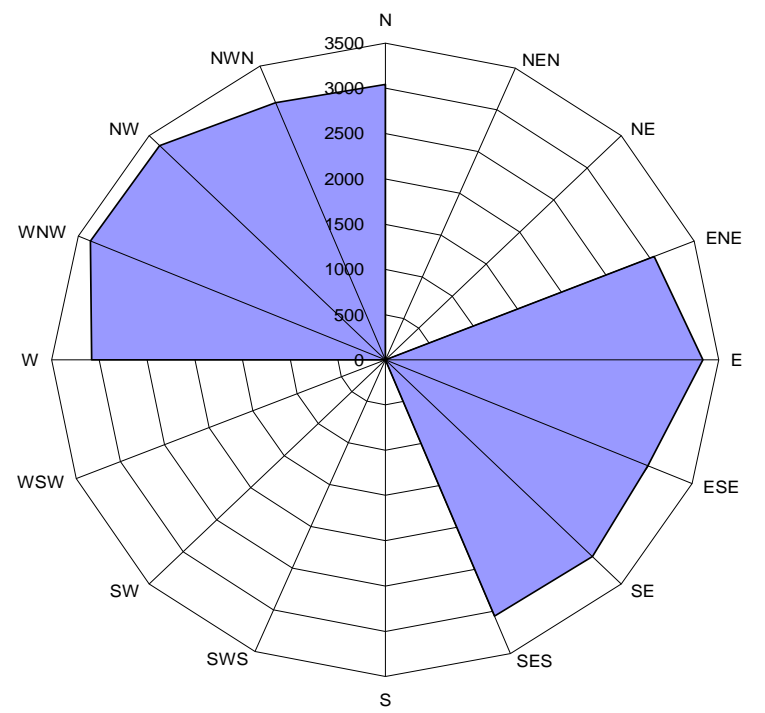

Fig. 7: The concentration rose of the highest fifty values of the hourly average concentrations of $\mathrm{SO}_{2}\left(\mu \mathrm{g} \mathrm{m}^{-3}\right)$ for the year 2001

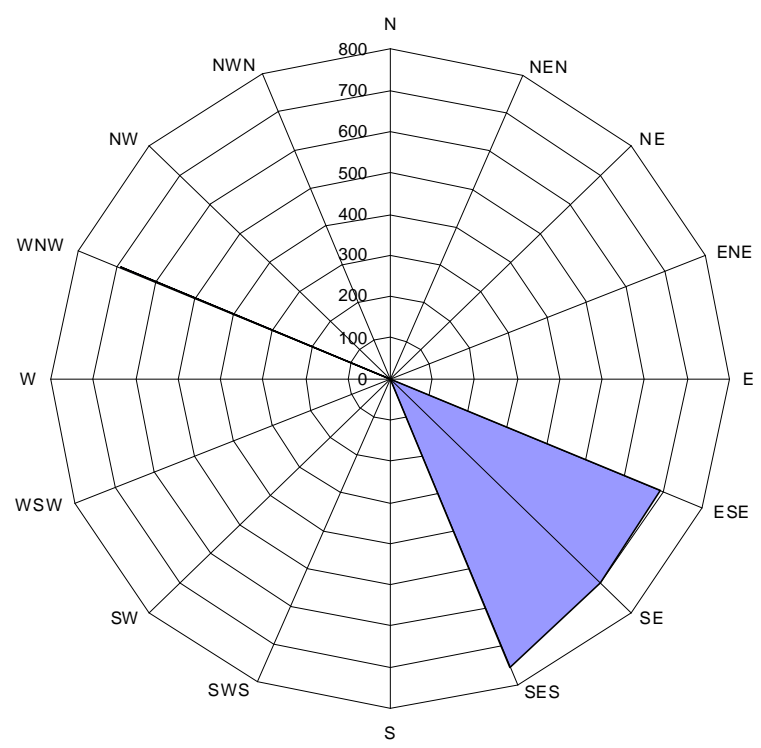

Fig. 8: The concentration rose of the highest fifty values of the daily average concentrations of $\mathrm{SO}_{2}\left(\mu \mathrm{g} \mathrm{m}^{-3}\right)$ for the year 2001

spread in the isopleths diagram is in all directions, however it retains its characteristics of being strongly influenced by the wind direction. On annual basis, the violation of limit set by Kuwait-EPA is small and is restricted to a nominal area around the Doha power station. The Doha power station's plume passes over larger residential area compared to Subyia power 
station's plume, which is built on the northeastern tip of the Kuwait Bay, resulting in the dispersion of the pollutants over the Bay.

As shown in the Fig. 9 and 10 the pollutant concentrations rose of nitrogen oxide (NOx) based on predicted daily values are dominant in the SE direction. The highest daily value is $79 \mu \mathrm{g} \mathrm{m}^{-3}$, on the 9 th of July 2001, $1.4 \mathrm{~km}$ from Doha plant and $157^{\circ}$ bearing north. The second highest value is $78 \mu \mathrm{g} \mathrm{m}^{-3}$, on the $3 \mathrm{rd}$ of July $2001,0.5 \mathrm{~km}$ from Subyia station and $59^{\circ}$ bearing north.

The NOx isopleths diagram shows considerable similarity with $\mathrm{SO}_{2}$ isopleths but with significantly lower concentrations. The highest hourly value observed is $422 \mu \mathrm{g} \mathrm{m}^{-3}$, on 3rd of August 2001, $1.6 \mathrm{~km}$ from Doha station and $86^{\circ}$ bearing north. The second highest value observed was $375 \mu \mathrm{g} \mathrm{m}^{-3}$, on the same day, $1.6 \mathrm{~km}$ from Doha station and $80.74^{\circ}$ bearing north. These values occurred at 4:00 am. In both cases illustrating the influence prevalence of meteorological conditions. The daily and hourly values of NOx show a similar variation to the one found for $\mathrm{SO}_{2}$.

As is clear from Fig. 11 the total violated area for average daily $\mathrm{SO}_{2}$ is equal to $136.3 \mathrm{~km}^{2}$, which in about $5.7 \%$ of the total area under consideration. High daily concentrations of up to $1000 \mu \mathrm{g} \mathrm{m}^{-3}$ were observed in the uninhibited area between the Doha power station and Doha residential area.

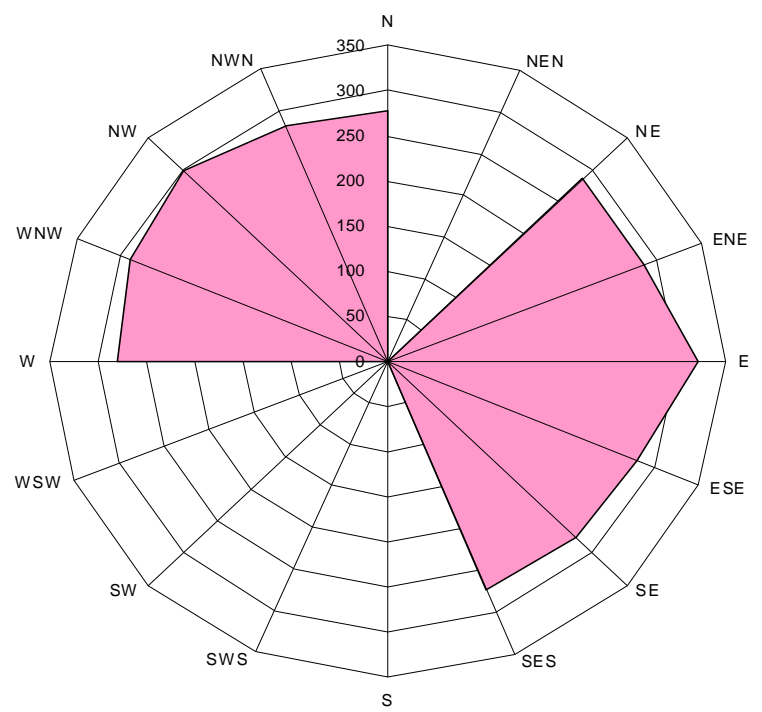

Fig. 9: The concentration rose of the highest fifty values of the hourly average concentrations of NOx $\left(\mu \mathrm{g} \mathrm{m}^{-3}\right)$ for the year 2001
Annual mean predicted $\mathrm{SO}_{2}$ concentrations has exceedance over $3.9 \mathrm{~km}^{2}$ area that represented about $0.16 \%$ of the total area under study, (Fig. 12). However, as is shown in Fig. 12 that this area covers Doha residential area, which is located at a distance of $6.5 \mathrm{~km}$ from the Doha power station where concentration levels are between 40 and $80 \mu \mathrm{g} \mathrm{m}^{-3}$. The predicted highest average annual concentration were in the range of 150-200 $\mu \mathrm{g} \mathrm{m}^{-3}$, (represented by the light green color band).

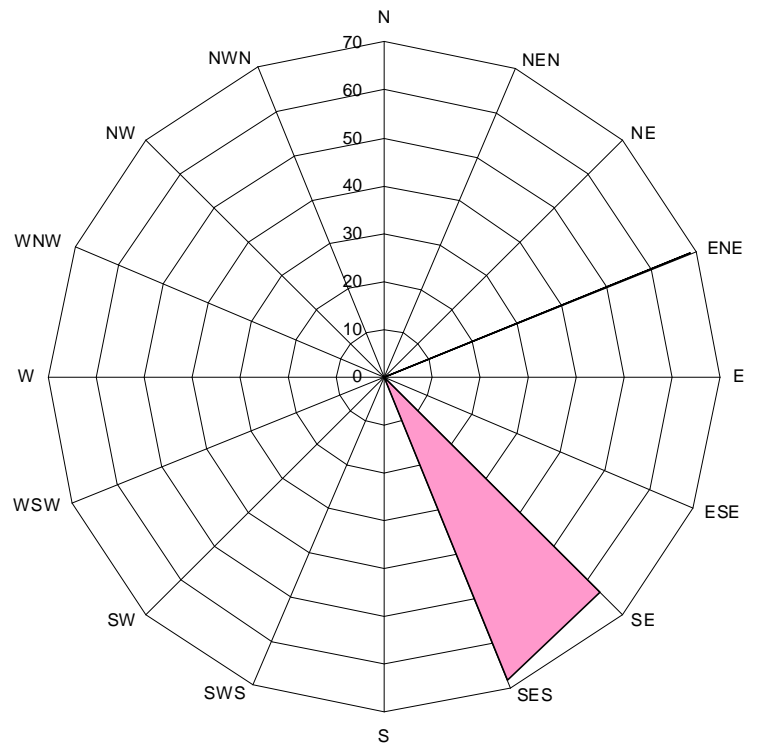

Fig. 10: the concentration rose of the highest fifty values of the daily average concentrations of NOx $\left(\mu \mathrm{g} \mathrm{m}^{-3}\right)$ for the year 2001

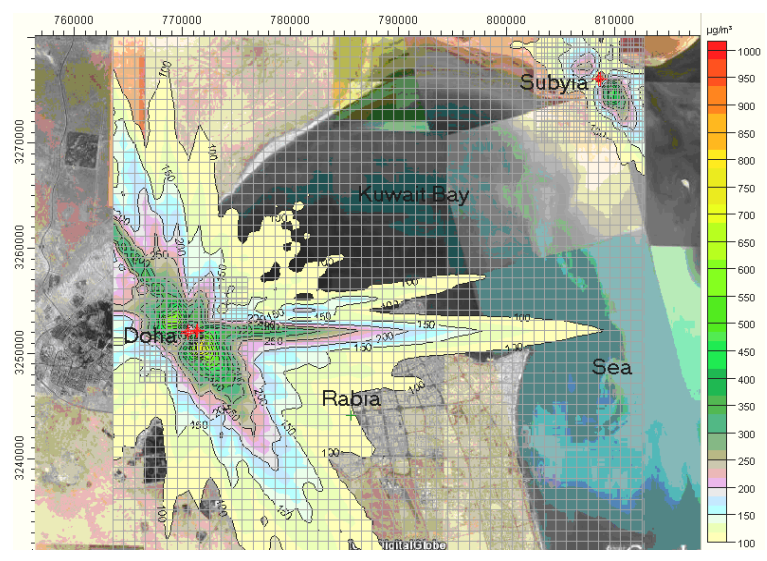

Fig. 11: Isopleths plot for the maximum daily average ground level concentrations of $\mathrm{SO}_{2} \mu \mathrm{g} \mathrm{m}^{-3}$ 


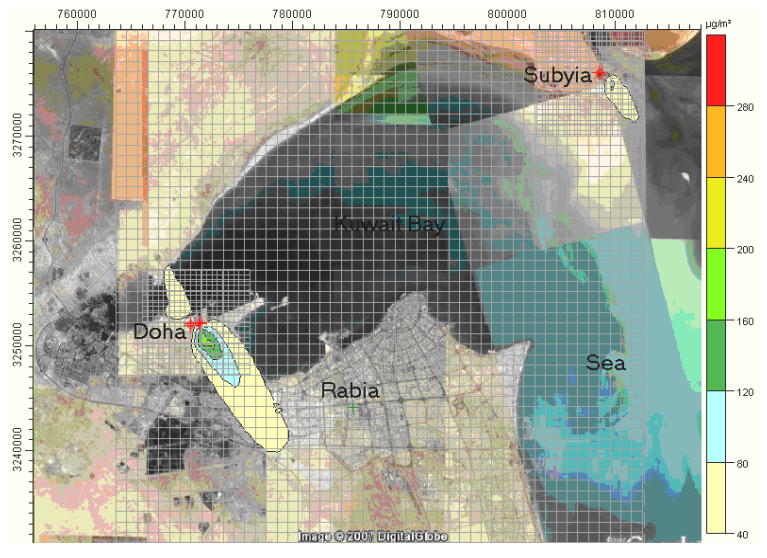

Fig. 12: Isopleths plot for the maximum annually average ground level concentrations of $\mathrm{SO}_{2} \mu \mathrm{g} \mathrm{m}^{-3}$

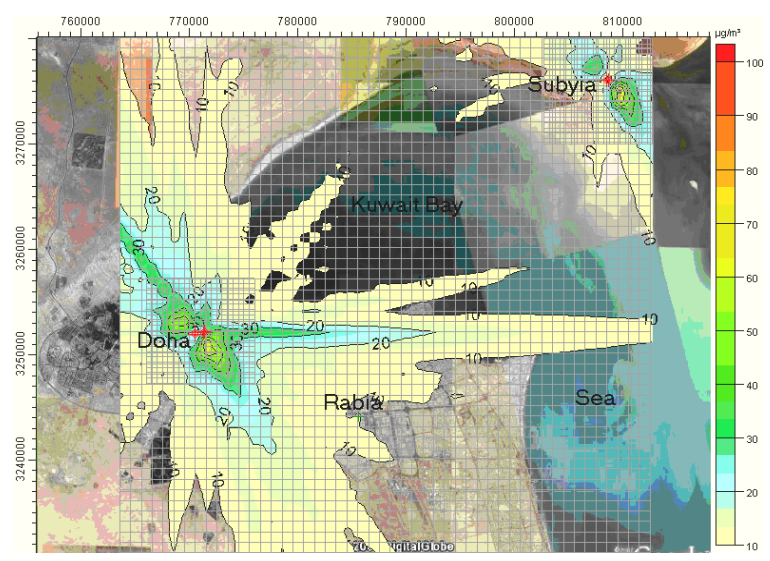

Fig. 13: Isopleths plot for the maximum daily average ground level concentrations of NOx $\mu \mathrm{g} \mathrm{m}^{-3}$

The daily Kuwait EPA limit for $\mathrm{SO}_{2}$ concentrations is $157 \mu \mathrm{g} \mathrm{m}^{-3}$. Therefore, other residential areas like, Rabia Aundulus, Farwania and Ferdous are at a safe distance away from the area of influence. The predicted highest daily $\mathrm{SO}_{2}$ concentration was $50 \mu \mathrm{g} \mathrm{m}^{-3}$. In the case of Subyia power station, the predicted high concentration exceeded the Kuwait EPA limits but these areas evenly distributed over the Kuwait bay area ensuring minimal impact on the residential or uninhibited area.

Kuwait EPA has set hourly, daily and annual limits for $\mathrm{NO}_{2}$ concentrations in the ambient area but there is no specific limit for NOx. Considering the same limit for $\mathrm{NOx}$ as $\mathrm{NO}_{2}$ the impact of $\mathrm{NOx}$, emissions from the power station are discussed below. Figure 13 and 14 show that the daily area of influence reached almost $66.8 \mathrm{~km}^{2}$, a mere $2.8 \%$. There is also no violation of limits based on mean annual concentration values.

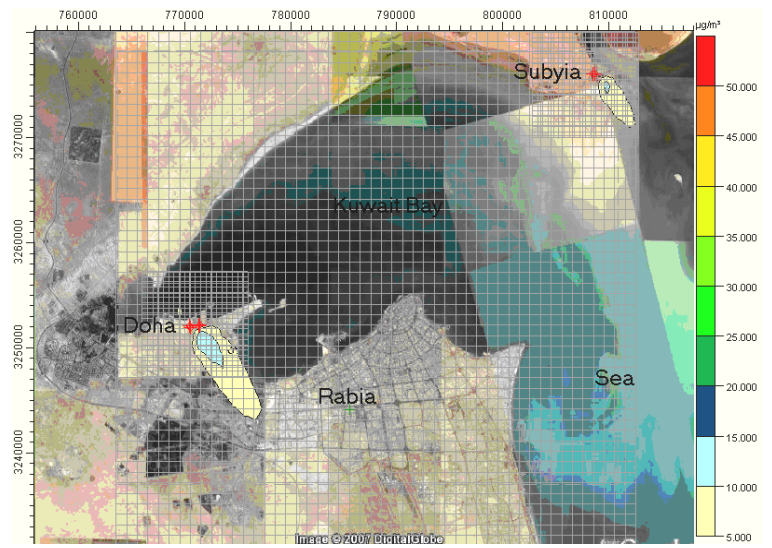

Fig. 14: Isopleths plot for the maximum annually average ground level concentrations of NOx $\mu \mathrm{g} \mathrm{m}^{-3}$

The set KE-EPA limit on the hourly scale is $224 \mu \mathrm{g} \mathrm{m}^{-3}$ and daily scale is $112 \mu \mathrm{g} \mathrm{m}^{-3}$. The predicted high concentrations are around the Doha power station, which drops quickly as the distance from the source increases, reaching to a safe daily mean concentration of $75 \mu \mathrm{g} \mathrm{m}^{-3}$, at Rabia.

Overall, it can be concluded that the model generates reliable and useful data, which can effectively be used for the prediction of pollutant concentrations from different emission sources.

\section{CONCLUSION}

Emission inventories from two major power generation facilities at Doha and Subyia have been analyzed with seasonal variation in their power output. Meteorological data for year 2001 were obtained from Kuwait International Airport and used as input in PCRAMMET software to determine stability class and upper air data to generate compatible data file for implementation of the dispersion model. This data with all other specifications from Power stations, stack characteristics, flue gas flow, exit temperature and exit velocity at stack tip with local terrain detail were fed to the Source Complex for Short-term Dispersion (ISCST4.5).

The computed results for $\mathrm{SO}_{2}$ and $\mathrm{NOx}$ inventories have been presented in details. The average dailypredicted $\mathrm{SO}_{2}$ concentrations were compared with discrete receptor "Rabia Air Quality Monitoring Station" real time measurements to validate the model output. It was concluded that hourly $\mathrm{SO}_{2}$ concentrations has large area under exceedance from Doha Power plant that included many residential and urban communities. 
Daily and annual mean predicted $\mathrm{SO}_{2}$ concentrations had exceedance only $5.7 \%$ and $0.16 \%$ respectively of the total area under investigation. There is no specified limit for NOx but KEPA has hourly limit for $\mathrm{NO}_{2}$ equal to $224 \mu \mathrm{g} \mathrm{m}^{-3}$ daily mean $112 \mu \mathrm{g} \mathrm{m}^{-3}$ and annual mean concentration $67 \mu \mathrm{g} \mathrm{m}^{-3}$. If NOx levels are considered equivalent to $\mathrm{NO}_{2}$, large area has been over the limit for hourly average concentration. There was $2.8 \%$ of the total area under exceedance based on daily average NOx concentrations and there was no violation based on average annual concentrations.

\section{REFERENCES}

1. Gokhale, S. and M. Khare, 2004. A review of deterministic, stochastic and hybrid vehicular exhaust emission models. Int. J. Transport Manage., 2: 59-74.

2. Kolehmainen, M., H. Martikainen and J. Ruuskanen, 2001. A Neural networks and periodic components used in air quality forecasting. Atmospher. Environ., 35: 815-825.

3. Brunekreef, B. and S.T. Holgate, 2002. Air pollution and health. Lancet, 360: 1233-1242.

4. Ministry of Electricity and Water (MEW) State of Kuwait, 2002. Statistical Year Book 2001 Electrical Energy, Edition, 27 "A".

5. Bouhamra, W.S. and S.A. Abdul-Wahab, 1999. Description of outdoor air quality in a typical residential area in Kuwait. Environ. Pollut., 105: 221-229.

6. Fox, D.G., 1981. Judging air quality performance: A summary of the AMS workshop on dispersion model performance. Bull. Am. Meteorol. Soc., 62: 599-609.
7. US Environmental Protection Agency, 1995. User's Guide for the Industrial Source Complex (ISC4.5) Dispersion Models. In: User Instructions, vol. I. US. Environmental Protection Agency and Research Triangle Park, North Carolina 27771. EPA-454/B-95-003a.

8. Al-Rashidi, M.S., V. Nassehi and R.J. Wakeman, 2005. Investigation of the Efficiency of Existing Air Pollution Monitoring Sites in the State of Kuwait. Environ. Pollut., 138: 219-229.

9. Abdul-Wahab, S.A., W. Bouhamra, H. Ettouney, B. Sowerby and B.B. Crittenden, 1999. Prediction of air pollution around heavily industrialized areas: Use of the industrial source complex short-term model with emissions from a large number of sources. IChemE Environ. Prot. Bull., 58: 3-13.

10. Al-Sudairawi, M. and K.P. Mackay, 1988. Evaluating the performance of the industrial source complex-(short term) model. Environ. Software, 3: $180-185$.

11. Malmaeus, J.M. and L. Håkanson, 2003. Optimal a dynamic model to predict suspended particulate matter in lakes, Ecol. Model., 167: 247-262.

12. Turner, D.B., 1970. Work book of Atmospheric Dispersion Estimates. AP 26 (NTIS PB 191-482). US EPA, Research Triangle Park, NC.

13. US Environmental Protection Agency, 1999. PCRAMMET User's Guide. EPA-454/B-96-001, US. Environmental Protection Agency, Office of Air Quality Planning and Standards Emissions, Monitoring and Analysis Division Research Triangle Park, NC 27711. 